\title{
29
}

\section{Prevention of transnational environmental crime and regulatory pluralism}

\author{
Julie Ayling
}

\section{Introduction}

Transnational environmental crime includes offences such as the illegal taking and trafficking of wildlife and timber, the international dumping of toxic waste and the trade in illicit ozone-depleting substances. Several features distinguish the current regulation of transnational environmental crime (TEC) from the regulation of environmental behaviour at the domestic level.

Domestically, there is increasing use of the concepts of responsive regulation and smart regulation, involving regulatory pyramids, combinations of policy instruments and a broad range of regulatory actors (see John Braithwaite, Chapter 7; and Gunningham and Sinclair, Chapter 8, this volume; Gunningham 2009; Pink 2013). However, states have, when dealing with TEC, almost exclusively focused on law enforcement, at the peak of the regulatory pyramid. The exploration of other possible responses to TEC - at the lower levels of the regulatory pyramid and harnessing actors other than the state-is still in its infancy. This is largely because recognition of the enormous environmental, social and economic consequences of TEC, both for individual countries and at a global scale, is a relatively recent phenomenon. 
Second, responding to TEC is often more complex than responding to domestic environmental harms. TEC crosses borders, so, if it is to be dealt with comprehensively, cooperation between jurisdictions is necessary. The transnational nature of the crimes also means they require varying degrees of organisation, ranging from simple small-group transactions to complex networked business models. Increasingly, we are seeing the involvement of organised criminal groups in many TECs, including groups known for other transnational crimes such as drug trafficking and terrorism. This trend raises concerns for states about national and international security.

Third, prevention rather than just control is crucial in dealing with TEC. Transnational environmental crime can result in the complete demise of an environmental resource (for example, the extinction of a species) or in irreversible damage to the environment that has global implications. Prevention requires a whole-of-society approach; however, preventive approaches are still fairly rare even at the domestic level of environmental regulation, and certainly in the field of organised crime.

This chapter demonstrates how a combination of regulatory and criminological theories suggests some additional ways of approaching the prevention of TEC.

\section{Current responses to transnational environmental crime}

Together with legal economic activities (mining, logging and urban expansion) and climate change, TECs pose serious threats to biodiversity, human wellbeing and the preservation of healthy ecosystems. The monetary value of all organised transnational environmental crime has been estimated at between US $\$ 70$ billion and US $\$ 213$ billion (AU\$92-280 billion) annually (Nellemann et al. 2014). There has been a rapid escalation in the volume of some forms of TEC in the past few years, such as the illicit trade in 'luxury' goods like ivory and rosewood, related mostly to an upswing in demand from the growing middle classes of developing countries.

An understanding of the nature of TECs and how to respond to them has been slow in coming and is still patchy. In many jurisdictions, laws to deal with these crimes are inadequate, penalties are low, enforcement 
of such laws as exist is lax and these crimes are viewed as victimless and therefore of low priority. However, calls for action to combat TECs have increased over the past couple of years. These calls have come from both states and international organisations such as the United Nations (UN) General Assembly, the European Parliament, the Asia-Pacific Economic Cooperation (APEC) Forum, the G8 and the International Criminal Police Organization (INTERPOL). This is due largely to a new recognition of the broader social, economic and political implications of TEC. A recent report by the UN Environment Programme (UNEP) and INTERPOL (Nellemann et al. 2014), dealing with the illicit trade in wildlife and forest resources, points out that this trade not only damages environmental sustainability, it also obstructs sustainable economic development, reduces domestic revenues, interferes with livelihoods and undermines good governance and the rule of law, particularly in still-developing nations. The prospect of the extinction of certain iconic species such as rhinos, tigers and elephants if illegal poaching is left unchecked has also helped motivate states to think more deeply about how to respond to these threats. So, too, has evidence of a growing involvement on the part of both organised crime and 'terrorist' groups (militias, insurgent groups) in perpetrating many of these crimes.

However, responding to TEC is a tough challenge. Many TECs are complex in nature, involving diverse offenders, victims, motivations, modi operandi and outcomes. ${ }^{1}$ In addition, these crimes cross borders, complicating the task of responding to them. There is, therefore, no 'onesize-fits-all' solution. Policing strategies, penalties and other responses need to be tailored to the particular crime and its specific context.

Until now the chief response of states and international organisations has been to strengthen law enforcement. Transnational environmental crimes do not lack legal frameworks, with an abundance of applicable

1 Consider, for example, the variety of crimes that can be categorised as 'wildlife crime' (Wyatt 2013): crimes involving the taking and trading of a variety of nonhuman animals and plants, serving different markets such as those for collectors' items or traditional medicines, perpetrated by differently motivated offenders ranging from opportunistic individuals to highly organised crime groups, and resulting in different victims at varying distances from the actual act, including the species, humans (both individuals and societies), states and the environment itself. 
treaties $^{2}$ and many interested international, regional and domestic institutions. ${ }^{3}$ Funding and support for law enforcement operations and new technologies for detection and investigation, as well as better resourcing and training of frontline enforcement agencies of various types (police, rangers, customs agencies, port and airport officials, and so on), have increased in recent years. But law enforcement is an expensive business and the financial outlay by states has not kept up with the need.

Moreover, so far, these investments have had a limited impact on TEC, particularly in terms of its prevention. This is well illustrated by data on poaching and trafficking of rhinoceros horn - a product highly valued in many Asian countries for its supposed medicinal benefits as well as for the status its possession brings (Milliken and Shaw 2012; Ayling 2013b). As Figure 29.1 illustrates, poaching of rhinos in South Africa increased by more than 9,200 per cent between 2007 and 2014. Figures issued by the South African Department of Environmental Affairs indicate that, while arrests for poaching increased from 2010 (when figures first became available) to 2014 and there was a small drop in 2015, poaching has shown little sign of diminishing.

2 For example, 1973 Convention on International Trade in Endangered Species of Wild Fauna and Flora (CITES); 1979 Convention on the Conservation of Migratory Species of Wild Animals (CMS or Bonn Convention); 1987 Vienna Convention for the Protection of the Ozone Layer (Vienna Convention) and Montreal Protocol on Substances that Deplete the Ozone Layer (Montreal Protocol); 1989 Basel Convention on the Control of Transboundary Movements of Hazardous Wastes and their Disposal (Basel Convention); 1992 Convention on Biological Diversity (CBD). It should be noted that these treaties predominantly regulate trade rather than criminalise it. 3 For example, at the international level, there are intergovernmental organisations such as the CITES Secretariat, INTERPOL, the UN Environment Programme (UNEP) and UN Office on Drugs and Crime (UNODC), and organisations involving partnerships between states and civil society such as the International Union for Conservation of Nature (IUCN), TRAFFIC and the International Network for Environmental Compliance and Enforcement (INECE); at the regional level are bodies such as the Association of Southeast Asian Nations Wildlife Enforcement Network (ASEAN-WEN), the Asian Environmental Compliance and Enforcement Network Initiative (AECEN) and the Australasian Environmental Law Enforcement \& Regulators network (AELERT); and, at the domestic level, there are governmental environmental ministries and subnational networks. 


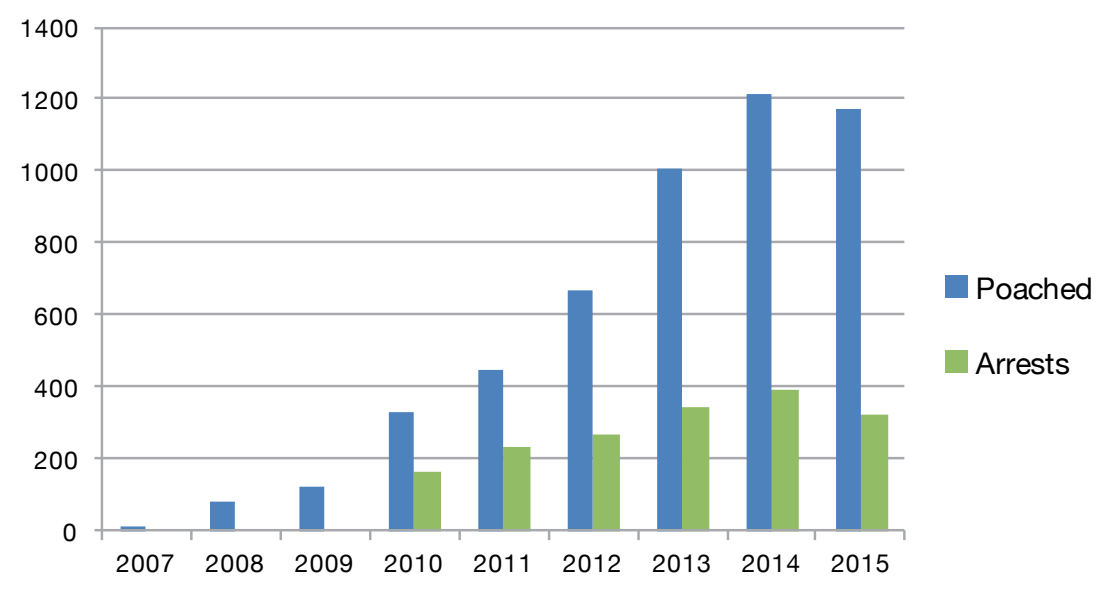

Figure 29.1 Rhinoceros poaching statistics, South Africa

Source: Author's research; data drawn from South African Department of Environmental Affairs.

It is not surprising that traditional law enforcement techniques only go so far towards preventing transnational environmental crimes. Deterrence theory tells us that the efficacy of deterrence is dependent on offenders' perceptions of the likelihood of punishment (Beccaria 1995; Erickson et al. 1977; Williams and Hawkins 1986; Nagin 1998). However, punishment is anything but likely for most perpetrators of TEC. As well as weak penalties and problems with investigation and enforcement, there are often impediments to law enforcement efficacy relating to intra and interstate agency capacity and coordination and public corruption.

So, the issue is: if the capacity of law enforcement to prevent TEC is imperfect, what else can be done? By using both regulatory and criminological theories, we can go some way towards answering that question.

\section{Beyond law enforcement}

Third parties-non-state, non-offending actors-have the potential to be active participants in crafting and implementing strategies to prevent TEC; that is, to be involved in its 'policing'. Policing as a concept encompasses crime prevention and law enforcement activities by many more actors than simply traditional law enforcement agencies. Over recent decades, policing has become multilateralised or pluralised 
(Bayley and Shearing 2001; Brewer, Chapter 26, this volume). Pluralised policing is largely a product of the turn to neoliberalism in the late twentieth century that 'hollowed out' the state (Rhodes 1994) as greater efficiency in public administration was sought and more emphasis was placed on markets to solve problems, including environmental ones (Gunningham 2009). This new hybrid governance of policing (Grabosky 1995b) - involving not only state institutions but also business, community groups and individual citizens-reflects wider societal shifts from state-centric 'government' to 'decentred, at-a-distance forms of state regulation' (Braithwaite 2000: 222) and towards governance performed by many actors (Rhodes 1997).

\section{Identifying third parties}

The third parties that have the most potential to be effective providers of TEC policing are those that are positioned at what Bullock et al. (2010: 2) call 'pinch-points for intervention' - that is, at places along the crime script ${ }^{4}$ where opportunities occur to disrupt or derail the crime. This is known in criminology as a situational crime prevention (SCP) approach because it focuses not on the offender but on manipulating the crime's social and physical settings to prevent the crime. SCP seeks to reduce opportunities for crime by increasing the efforts and risks and diminishing the rewards associated with the crime.

Generally, SCP has emphasised potential interventions by traditional law enforcement agencies in the crime script. However, often third parties, not police or other law enforcement agencies, are the ones who will be on hand at pinch-points to influence the course of the crime.

What kinds of roles can and do such third parties play in relation to TEC? Routine activities theory (RAT) suggests one answer. RAT underpins the situational crime prevention approach and has been summed up by Eck (2003: 88) as follows:

[A] crime is highly likely when an offender and a target come together at the same place, at the same time, and there is no one nearby to control the offender, protect the target, or regulate conduct at that place.

4 The crime script consists of the different steps that make up the particular crime. Crime scripts vary from crime to crime and commodity to commodity (see Cornish 1994). 
Controlling offenders (handlers), protecting victims (guardianship) and regulating conduct in places where crime takes place (place management) are all roles that various third parties positioned along the crime script may be able to perform to help prevent TEC. Thinking again about rhinoceros poaching, we might, for example, imagine a situation in which a community group involved in a conservancy, ${ }^{5}$ or a company engaged in an industry such as forestry or mining, employs at a decent wage those who might otherwise poach rhinos (thus, handling potential offenders), guards the rhinos on their patch and manages the potential crime site by preventing poachers' access to the area with fencing and secure gates.

Mapping the third parties who could possibly play the roles of handlers, guardians and place managers in different TEC scenarios would be a first significant step towards a better understanding of how various transnational environmental crimes might be prevented. Of course, there will be many third parties who are able to play only one or two of these roles, not all three. Banks and other financial parties, for example, are in a position as potential handlers to be vigilant about to whom they lend and in checking suspicious transactions, especially when those transactions form patterns over time. Indeed, lists of third parties who may play an intervention role to prevent TEC will often include financial parties and transport and warehousing firms. Other possible roles for third parties include demand reduction (through, for example, consumer education) and anticorruption activities (detection, prevention).

\section{Coordinating prevention: The role of the state}

It is one thing to identify the many non-state, non-offending parties who can play a part in preventing TEC. It is quite another to assume that all those parties will be ready, willing and able to undertake that task. Crime prevention can be an onerous and unwelcome job. And, where third parties do have the capacity and willingness to act, as is the case with many non-governmental organisations (NGOs) dedicated to protecting wildlife and forests, not all of them may be in agreement over strategies. Diverse ideologies can lead to clashing agendas and different ideas about appropriate responses to environmental harms, including

5 A conservancy is a grassroots organisation dedicated to protecting and preserving the environment of a designated area. Many hundreds of conservancies exist across Africa. 
how important it is to stay within the limits of the law (White 2012). In short, third parties face a range of transaction and negotiation costs that complicates their ability to effectively act and collaborate on crime prevention.

So, it is important, then, to think about how the capacities of third parties to prevent TEC can be harnessed. The aims of ensuring that those who can contribute to prevention do, and that any contributions are actively constructive, will be best served if there is some coordination of activities to that end.

Who is in the best position to do this job of coordination? States are really the only ones that have a full array of mechanisms (see below) available to catalyse preventive action by a wide range of actors, including the ability to coerce intransigent third parties. Of course, states may not always be capable of coordinating crime prevention activities. Weak states sometimes lack capacity to tackle crime problems at all, and civil society and private transnational institutions may then step in to compensate for this inadequacy in innovative ways. However, to coordinate a wholeof-society response to prevent a cornucopia of crime problems that are transnational in nature is something that requires a greater reach than is typically within the power of a single private party. Strong states can support weak ones in this endeavour, as they already do in relation to state-led actions to control TEC.

Although some of the academic literature relating to TEC has dealt with SCP and the role of non-state actors (see, for example, Graycar and Felson 2010; Wellsmith 2010; Schneider 2012; Lemieux 2014), the ways in which governments could systematically catalyse the broad potential of those third parties to contribute their own capacities in the pursuit of preventive outcomes have not been a focus.

\section{Catalysing third parties: Mechanisms}

The coordinating role the state can play in relation to third parties is not limited to regulation as traditionally understood, but extends beyond rulemaking to purposefully influencing the flow of events in any of a number of ways (Parker and Braithwaite 2003). The theory of responsive regulation indicates that the manner in which states approach the task of regulation needs to be context sensitive-that is, alive to the (non)compliance stance of the potential regulatee and able to adapt 
to any changes in that stance (see John Braithwaite, Chapter 7, this volume). This suggests that states should consider adopting a repertoire of regulatory strategies for TEC prevention and choose between them according to the intended regulatee. In this way, the state can 'responsibilise' third parties and encourage or command them to use their capacities to prevent TEC.

The strategies the state can use to harness the capacities of third parties to enhance security generally have been examined by Grabosky and his colleagues (Grabosky 1995b; Cherney et al. 2006). These range along a continuum of mechanisms, from coercive to non-coercive, allowing the state to choose a strategy that takes into account the seriousness of the situation it faces and how willing a particular third party is to contribute their capacities. Brewer (2014) has represented these strategies diagrammatically (Table 29.1).

Table 29.1 Mechanisms used to facilitate community coproduction

\begin{tabular}{|c|c|c|}
\hline Mechanism & Description & \\
\hline Conscription & $\begin{array}{l}\text { Mandating/commanding external institutions } \\
\text { through such mechanisms as legislation to carry out } \\
\text { prescribed functions to limit the opportunities for } \\
\text { crime }\end{array}$ & Most coercive \\
\hline $\begin{array}{l}\text { Required } \\
\text { private interface }\end{array}$ & $\begin{array}{l}\text { Requiring that targets of regulation interface with } \\
\text { another private actor who is well placed to detect, } \\
\text { prevent and disclose illegality on the part of their } \\
\text { clients }\end{array}$ & \\
\hline $\begin{array}{l}\text { Required } \\
\text { record-keeping } \\
\text { and disclosure }\end{array}$ & $\begin{array}{l}\text { Requiring the keeping and disclosure of records to } \\
\text { prescribed authorities, with the aim being to enhance } \\
\text { self-awareness and vigilance on the part of managers }\end{array}$ & \\
\hline $\begin{array}{l}\text { Cooptation } \\
\text { of external } \\
\text { interests }\end{array}$ & $\begin{array}{l}\text { Actively seeking the cooperation of external } \\
\text { institutions in furtherance of crime control. The } \\
\text { formality of these arrangements can vary, from } \\
\text { detailed contractual specification to informal requests } \\
\text { persuading external institutions to take crime control } \\
\text { actions }\end{array}$ & \\
\hline $\begin{array}{l}\text { Conferring } \\
\text { entitlements }\end{array}$ & $\begin{array}{l}\text { Using new or pre-existing entitlements to persuade } \\
\text { third parties to take crime control actions }\end{array}$ & \\
\hline Incentives & $\begin{array}{l}\text { Offering incentives as a means of inducing institutions } \\
\text { or individuals to comply with policies/processes/ } \\
\text { procedures aimed at discouraging crime }\end{array}$ & \\
\hline $\begin{array}{l}\text { Education/ } \\
\text { capacity- } \\
\text { building }\end{array}$ & $\begin{array}{l}\text { Providing training and educational programs to raise } \\
\text { awareness among external parties regarding agency } \\
\text { responsibility and the capacity to prevent criminal } \\
\text { activity }\end{array}$ & $\begin{array}{l}\text { Least } \\
\text { coercive }\end{array}$ \\
\hline
\end{tabular}

Source: Adapted from Brewer (2014: 52). 
While there is not the space in this chapter to examine these strategies in any detail, ${ }^{6}$ they are briefly summarised below, together with one or two examples of how relevant third parties have been or might be catalysed to play a role in preventing TEC.

\section{Conscription}

The state could legislatively impose mandatory obligations on third parties to carry out certain actions or to report certain information, with penalties for noncompliance.

Example: The state could require privately held stockpiles of ivory and rhino horn to be registered on a secure government-operated register or actually surrendered to government for safekeeping or disposal, with the dual aims of reducing the amount of stock potentially available for trading on the black market and deterring market speculation, which provides an incentive for poaching (Mason et al.2012).

\section{Required private interface}

By requiring potential offenders to 'use the machinery of private institutions', the state can harness the capacity of third parties (the private institutions) as 'gatekeepers' at the legal-illegal interface.

Example: Governments could require private businesses involved in the logging of timber concessions to have their records audited by formally accredited professional institutions to ensure that harvest, export and financial records match up and comply with legal allowances.

\section{Required record-keeping and disclosure}

The state often requires record-keeping to ensure that it has access to information, but record-keeping requirements also open the possibility that the record-keeper (third party) will spot anomalies that indicate that a crime may be or is being committed and either report this to the authorities or personally intervene to close a criminal opportunity.

6 For a more detailed description and further examples, see Ayling (2013a). 
Example: Online auction houses such as eBay could be required to keep records of all attempts to trade endangered species products through their sites, thus requiring these third parties to undertake a surveillance role that could assist in closing down a trafficking opportunity.

\section{Cooptation of external interests}

Formal and informal partnerships between states and non-state actors (third parties) are common in the environmental area at a domestic level, and are becoming increasingly common with respect to TEC.

Examples: In many African countries, state-registered conservancies are charged with protecting and conserving the environment of a designated area, often with state funding and sometimes funded by their own activities (for example, tourism). Such public recognition of the important role of local residents in environmental protection can significantly increase the value a community ascribes to its area's biodiversity and its willingness to take TEC prevention measures. The existence of motivated conservancies may itself have a chilling influence on criminal activity.

NGOs often work in partnership with international organisations to respond to TEC. For instance, the International Fund for Animal Welfare (IFAW) has long collaborated with INTERPOL on antiivory trafficking projects and currently helps to train law enforcement and customs officers at major East African airports in investigative techniques for wildlife crime (INTERPOL 2013).

\section{Conferring entitlements}

The state could create rights for third parties and the ability to enforce them in ways that will assist in TEC prevention.

Example: Private enforcement provisions already exist under domestic environmental statutes in some jurisdictions such as the United States and Australia. ${ }^{7} \mathrm{~A}$ further broadening of legislative standing requirements or the creation of additional rights could encourage third parties to take preventive action, say, with respect to other third parties with guardianship or place management responsibilities. 


\section{Incentives}

Using incentives can be more powerful than other more coercive strategies because they are often perceived as more legitimate (Grabosky 1995a). Direct incentives include the use of rewards for providing information to authorities or for capturing crime perpetrators; indirect incentives include tax deductions, administrative privileges and prizes.

Example: The US Lacey Act criminalises trafficking in the United States of wildlife taken in contravention of any foreign law. Under the Act, a reward account has been set up into which some of the fines levied under the Act are deposited and used to provide financial incentives for information leading to the arrest and conviction of violators. ${ }^{8}$

\section{Education and capacity-building/facilitation}

Education, capacity-building and other facilitative measures can enable third parties to better make use of their capacities to further the aim of crime prevention.

Examples: Training could be given in environmental law, investigatory skills, criminal justice processes and rules of evidence to NGOs and community groups that wish to assist with law enforcement activities. States could also assist these groups financially as they engage in consumer education programs and the development of certification schemes. For example, significant funding was provided by Austria towards the establishment of the Forest Stewardship Council (Bartley 2007).

\section{Regulatory risks}

Less intrusive regulation can be extremely powerful but regulating at a distance is not without risks and difficulties. The transnational nature of environmental crimes such as wildlife and timber trafficking makes coordinating crime prevention efforts complex. Organised criminal groups are adept at taking advantage of differences in regulation between

8 See 16 USC $\$ 3375(d)$. 
states, so, although it is hard, making efforts to coordinate efforts across jurisdictions not only in relation to law enforcement but also on thirdparty regulatory measures is worthwhile.

Potential third-party mobilisations also need to be thoroughly assessed for their likelihood of furthering the aim of preventing the targeted TEC and for possible unintended and undesirable consequences. This may require third parties to be verified as worthy of the state's trust, especially when being funded for crime prevention activities. Accountability mechanisms for third-party actions also need to be put in place. These mechanisms may need to be situated outside state jurisdictions to ensure a corruption-free process-perhaps in existing or bespoke intergovernmental or international bodies. Evaluation of TEC prevention measures is also desirable to ensure that states can learn what works in this area and not engage in constantly reinventing the wheel.

\section{Conclusion}

Reducing the impact of TEC needs a whole-of-society approach and calls on the state to take on, as it has in other areas of regulation, a much greater steering role. A more systematic approach to harnessing the many capacities of third parties for policing TEC, involving coordination by national governments alone or in combination, could be guided by work already done in relation to strategies for the coproduction of security generally. Although there are challenges to achieving this kind of coordination, it is clear that there is a need to go beyond law enforcement to counter criminal networks perpetrating TEC with a networked response that draws together the good work in the field already being done by third parties, albeit in an ad hoc way, both as individual initiatives and in partnership with or at the behest of governments.

As outlined here, coproductive regulatory strategies are readily applicable in the area of TEC prevention. This chapter has suggested that what is needed is the mapping of relevant third parties for particular types of TEC and the planning of appropriate responsive strategies that make use of their varied regulatory capabilities, including as guardians of TEC victims, handlers of TEC offenders and place managers of TEC sites. 


\section{Further reading}

Elliott, L 2012. 'Fighting transnational environmental crime', Journal of International Affairs 66(1): 87-104.

White, R (ed.) 2011. Transnational Environmental Crime: Towards an Eco-Global Criminology. Abingdon, UK: Routledge.

Wright, G 2011. 'Conceptualising and combating transnational environmental crime', Trends in Organized Crime 14(4): 332-46. doi. org/10.1007/s12117-011-9130-4.

\section{References}

Ayling,J 2013a.'Harnessing third parties for transnational environmental crime prevention', Transnational Environmental Law 2(2): 339-62. doi.org/10.1017/S2047102513000174.

Ayling, J 2013b. 'What sustains wildlife crime? Rhino horn trading and the resilience of criminal networks', Journal of International Wildlife Law and Policy 16(1): 57-80. doi.org/10.1080/13880292. 2013.764776.

Bartley, $\mathrm{T}$ 2007. 'Institutional emergence in an era of globalization: The rise of transnational private regulation of labor and environmental conditions', American Journal of Sociology 113(2): 297-351. doi.org/ $10.1086 / 518871$.

Bayley, D and Shearing, C 2001. The New Structure of Policing: Description, Conceptualization, and Research Agenda. Washington, DC: National Institute of Justice.

Beccaria, C 1995 [1764]. On Crimes and Punishments and Other Writings. R Bellamy, ed. \& R Davies, trans. Cambridge: Cambridge University Press. doi.org/10.1017/CBO9780511802485.

Braithwaite, J 2000. 'The new regulatory state and the transformation of criminology', British Journal of Criminology 40: 222-38. doi.org/ 10.1093/bjc/40.2.222. 
Brewer, R 2014. Policing the Waterfront: Networks, Partnerships, and the Governance of Port Security. Oxford: Oxford University Press. doi. org/10.1093/acprof:oso/9780199687367.001.0001.

Bullock, K, Clarke, RV and Tilley, N 2010. 'Introduction', in K Bullock, RV Clarke and N Tilley (eds), Situational Prevention of Organised Crime. Cullompton, UK: Willan, pp. 1-16. doi.org/10.21313/ hawaii/9780824833879.003.0001.

Cherney, A, O'Reilly, J and Grabosky, P 2006. 'Networks and metaregulation:Strategiesaimed at governing illicitsyntheticdrugs', Policing and Society 16(4): 370-85. doi.org/10.1080/10439460600973693.

Cornish, DB 1994. 'The procedural analysis of offending and its relevance to situational prevention', in RV Clarke (ed.), Crime Prevention Studies. Volume 3. Monsey, NY: Criminal Justice Press, pp. 151-96.

Department of Environmental Affairs 2015. Minister Edna Molewa highlights progress in the war against poaching and plans for 2015, Media release, 22 January, Department of Environmental Affairs, Republic of South Africa, Pretoria. Available at: environment.gov.za/ mediarelease/molewa_waragainstpoaching2015.

Eck, J 2003. 'Police problems: The complexity of problem theory, research and evaluation', Crime Prevention Studies 15: 79-113.

Erickson, ML, Gibbs, JP and Jensen, GF 1977. 'The deterrence doctrine and the perceived certainty of legal punishments', American Sociological Review 42: 305-17. doi.org/10.2307/2094607.

Grabosky, PN 1995a. 'Regulation by reward: On the use of incentives as regulatory instruments', Law and Policy 17(3): 257-82. doi.org/ 10.1111/j.1467-9930.1995.tb00150.x.

Grabosky, PN 1995b. 'Using non-governmental resources to foster regulatory compliance', Governance 8(4): 527-50. doi.org/10.1111/ j.1468-0491.1995.tb00226.x.

Graycar, A and Felson, M 2010. 'Situational prevention of organised timber theft and related corruption', in K Bullock, RV Clarke and NTilley (eds), Situational Prevention of Organised Crime. Cullompton, UK: Willan, pp. 81-92. 
Gunningham, N 2009. 'Environmental law, regulation and governance: Shifting architectures', Journal of Environmental Law 21(2): 179212. doi.org/10.1093/jel/eqp011.

International Criminal Police Organization (INTERPOL) 2013. INTERPOL and IFAW agreement boosts global fight against wildlife crime, Media release, 22 May, INTERPOL, Lyon. Available at: interpol.int/News-and-media/News-media-releases/2013/PR060.

Lemieux, AM (ed.) 2014. Situational Prevention of Poaching. Abingdon, UK: Routledge.

Mason, CF, Bulte, EH and Horan, RD 2012. 'Banking on extinction', Oxford Review of Economic Policy 28(1): 180-92. doi.org/10.1093/ oxrep/grs006.

Milliken, T and Shaw, J 2012. The South Africa-Viet Nam Rhino Horn Trade Nexus: A Deadly Combination of Institutional Lapses, Corrupt Wildlife Industry Professionals and Asian Crime Syndicates. Johannesburg: TRAFFIC. Available at: traffic.org/species-reports/ traffic_species_mammals66.pdf.

Nagin, DS 1998. 'Criminal deterrence research at the outset of the twenty-first century', in M Tonry (ed.), Crime and Justice: A Review of Research. Chicago: University of Chicago Press, pp. 1-42. doi.org/10.1086/449268.

Nellemann, C, Henriksen, R, Raxter, P, Ash, N and Mrema, E (eds) 2014. The Environmental Crime Crisis: Threats to Sustainable Development from Illegal Exploitation and Trade in Wildife and Forest Resources - A UNEP Rapid Response Assessment. Nairobi and Arendal, Norway: United Nations Environment Programme and GRIDArendal. Available at: unep.org/publications/.

Parker, C and Braithwaite, J 2003. 'Regulation', in P Cane and M Tushnet (eds), The Oxford Handbook of Legal Studies. Oxford: Oxford University Press, pp. 119-45.

Pink, G 2013. Law enforcement responses to transnational environmental crime: Choices, challenges, and culture, Working Paper 4/2013, Transnational Environmental Crime Project, The Australian National University, Canberra. Available at: ips.cap.anu.edu.au/ir/ tec/publications. 
Rhodes, RAW 1994. 'The hollowing out of the state: The changing nature of the public service in Britain', Political Quarterly 65: 138-51. doi.org/10.1111/j.1467-923X.1994.tb00441.x.

Rhodes, RAW 1997. Understanding Governance. Buckingham, UK: Open University Press.

Schneider, J 2012. Sold into Extinction: The Global Trade in Endangered Species. Santa Barbara, CA: Praeger.

Wellsmith, M 2010. 'The applicability of crime prevention to problems of environmental harm: A consideration of illicit trade in endangered species', in R White (ed.), Global Environmental Harm: Criminological Perspectives. Cullompton, UK: Willan, pp. 132-49.

White, R 2012. 'NGO engagement in environmental law enforcement: Critical reflections', Australasian Policing: A Journal of Professional Practice and Research 4(1): 7-11.

Williams, K and Hawkins, R 1986. 'Perceptual research on general deterrence: A critical overview', Law and Society Review 20: 545-72. doi.org/10.2307/3053466.

Wyatt, T 2013. Wildlife Trafficking: A Deconstruction of the Crime, the Victims, and the Offenders. Basingstoke, UK: Palgrave Macmillan. doi.org/10.1057/9781137269249. 
This text is taken from Regulatory Theory: Foundations and applications, edited by Peter Drahos, published 2017 by ANU Press, The Australian National University, Canberra, Australia. 